\title{
STUDY ON MECHANICAL PROPERTIES OF HIGH STRENGTH CONCRETE WITH SILICA FUME, FLYASH AND STEEL FIBER
}

\author{
Atul Ranjan \\ Assistant Professor, Department of Civil Engineering, \\ GIACR Engineering College, Rayagada, Odisha, India
}

\begin{abstract}
In this growing world there has always been a strong competition in the market amongst industries in term of economy, profits, shares etc. one such industry is construction industry where concrete is the key building substance which is in limelight. Since past, we have seen much advancement in concrete because of the research which is in progress on concrete to come out with a product which should be economical and strong enough to resist all kind of loads. In this thesis, fly ash and silica fume are used as a replacement for cement along with steel fibers by volume of concrete. Here, fly ash is replaced by $0 \%, 15 \%, 30 \%$ and silica fume is replaced by $0 \%, 6 \%, 12 \%$ and $18 \%$ for cement. Initially, a set of concrete specimens were casted with $0 \%, 15 \%, 30 \%$ fly ash and $0 \%, 6 \%, 12 \%$ and $18 \%$ silica fume with $0 \%$ addition of steel fibers and tested for compressive, flexural and split tensile strength. Secondly, another set of concrete specimens were casted with $0 \%, 15 \%$, $30 \%$ fly ash and $0 \%, 6 \%, 12 \%$ and $18 \%$ silica fume with $0.5 \%$ addition of steel fibers and tested for the same. Similarly, another set of samples were casted $0 \%, 15 \%, 30 \%$ fly ash and $0 \%, 6 \%$, $12 \%$ and $18 \%$ silica fume with $1 \%$ addition of steel fibers and tested to determine the mechanical properties of concrete. And it was observed that maximum compressive, flexural and split tensile strength was attained at $15 \%$ fly ash and $12 \%$ silica fume with $1 \%$ steel fiber.
\end{abstract}

Keywords - Silica fume, Fly ash, compressive strength, flexural strength, split tensile strength.

\section{INTRODUCTION}

\subsection{General}

Concrete, is one of the key construction materials having good compressive \&, flexural strengths and durable properties among others. With comparative low cost made from some of the most widely available elements, it has found wide usage. It is mouldable, adaptable and relatively fire resistant. The fact that it is an engineered material which satisfy almost any reasonable set of performance specifications, more than any other material currently available has made it immensely popular construction material. In fact, every year more than $1 \mathrm{~m}^{3}$ of concrete is produced per person (more than 10 billion tonnes) worldwide. Strength (load bearing capacity) and durability (its resistance to deteriorating agencies) of concrete structures are the most important parameters to be considered while discussing concrete. The deteriorating agencies may be chemical - sulphates, chlorides, $\mathrm{CO}_{2}$, acids etc. or mechanical causes like abrasion, impact, temperature etc. The steps to ensure durable and strong concrete encompass structural design and detailing, mix proportion and workmanship, adequate quality control at the site and choice of appropriate ingredients of concrete. Type of cement is one such factor. In this paper, the significance and effect of the type of cement on strength and durability of its corresponding concrete is focussed on.

\subsection{TRIBLE BLENDED HIGH STRENGTH CONCRETE}

At the commencement of a concrete construction, the anticipated exposure conditions generally decide the type of cement. Requirements of load-carrying capacity are met by the structural design of the members, which decide the required strength grade of concrete and strength class of cement. From logistic and management considerations, it helps if one cement can meet the diverse performance demands. Thus, in order to meet all these requirements, incorporation of high strength concrete into a new yet effective concept of triple blended concretes is considered a needful solution. The objective of doing so is to optimize the thrust in strength and durability parameters achieved by both triple blended cements as well as high strength concrete to obtain what is 
known as triple blended high strength concrete. But before proceeding further, let us understand thoroughly, what is high strength concrete?

Thus, combination of the two concepts of triple blended concrete and that of high strength concrete by the application of mineral admixtures such as silica fume and fly ash in concrete is an easy and effective way of enhancing the strength and durability parameters of the concrete in a large magnitude.

\subsection{FIBER REINFORCED CONCRETE}

Concrete has become so popular and indispensable, as aforementioned, due to its inherent characteristics and advantages. The use of reinforcement in concrete brought a revolution in the application of concrete. However generally, despite this, compared to other building materials such as metals and polymers, concrete is significantly more brittle and exhibits a poor tensile strength. Based on fracture toughness values, steel, in the form of reinforcement, is at least 100 times more resistant to crack growth than concrete. Concrete in service thus cracks easily, and this cracking creates easy access routes for deleterious agents resulting in early saturation, freeze-thaw damage, scaling, discoloration and steel corrosion.

Increases in the length, diameter ratio (called the aspect ratio) of the fibres usually augment the flexural strength and the toughness of the concrete. The values of this ratio are generally not kept too high as fibres which are too long tend to "ball" in the mix and create workability problems. As a rule, fibres are generally randomly distributed in the concrete so that after processing the concrete, the fibres become aligned in the direction of the applied stress and will thus result in greater tensile and flexural strength. Fibre reinforced concrete is slowly becoming a well accepted mainstream construction material. Significant progress has been made in the last thirty years towards understanding the short and long-term performances of fibre reinforced cementitious materials, and this has resulted in a number of novel and innovative applications.

\subsection{POZZOLANIC ADMIXTURES IN CONCRETE}

Admixture is defined as a material, other than cement, water and aggregates, that is used as an ingredient of concrete and is added to the batch immediately before or during mixing.
As per the report of the ACI committee 212, admixtures have been classified into 15 groups according to type of materials constituting the admixtures, or characteristic effect of the use.

- Plasticizers

- Super plasticizers

- Retarders and retarding Plasticizers

- Acceleration and Accelerating plasticizers

- Air-entraining admixtures

- Pozzolanic or Mineral Admixtures

- Damp-Proofing and Waterproofing Admixtures

- Gas forming Admixtures

- Air detraining Admixtures

- Alkali-Aggregate Expansion Inhibition Admixtures

- Workability Admixtures

- Grouting Admixtures

- Corrosion Inhibition

- Bonding Admixture

- Color Admixture

\subsection{SIGNIFICANCE OF TRIBLE BLENDED CONCRETE}

Although concrete has been serving human beings to provide amenities, the service comes with a significant price. Regarding the immense amount of concrete production annually, it has considerable impacts on the environment. Consumption of vast amount of natural resources, release of almost one tonne of $\mathrm{CO}_{2}$ into the atmosphere from the production of each tonne of Portland Cement are two major environmental issues. Worldwide, the cement industry alone is estimated to be responsible for about $7 \%$ of all $\mathrm{CO}_{2}$ generated. Moreover, regardless of water supply shortages in most parts of the world, the production of concrete requires large amounts of water. Finally, the demolition and need of disposal of concrete structures, pavements etc., creates another environmental burden. Construction and demolition debris produces a considerable fraction of solid waste in developed countries.

What is listed above indicates that concrete has become the victim of its own achievements but for sure it is still one of the most practical building materials in the world. The challenges that this industry is facing are more of a result of Portland cement production. So, the most effective remedy to solve the problem is to use less Portland cement which means to replace as much Portland cement as possible by supplementary cementitious materials in 
place of natural resources. Different efforts have been made to reduce the drawbacks of concrete on environment such as aggregates and binders. Furthermore, the partial replacement of Portland Cement with mineral admixtures proves itself to be an economical and cost-effective proposition. This is because, the cost of these admixtures, obtained as industrial bi-products, is much lesser than that of cement. And hence, the cost of any triple blended concrete mix is substantially lesser than that of its corresponding ordinary concrete. It is believed that the adverse effects of cement, $\mathrm{CO}_{2}$ emission, may be minimized if mineral tion, energy and cost. In eco cement, large amouadmixtures are applied; as they reduce cement consumpnts of Portland cement clinker (up to $70 \%$ ) are replaced by available mineral additives such as natural pozzolanic materials, sand, limestone, granulated blast furnace slag, fly ash, silica fume, glass cullet and ceramic wastes. A case study reveals that a reduction of up to $67 \%$ of the energy requirements and $80 \%$ in the cementing of pozzolanas added, energy requirements may drop by $33 \%$ and cost by $20 \%$.

This paper focuses on mineral admixtures used as a supplementary cementitious material in order to reduce Portland cement and how they enhance the properties of the corresponding concrete. Our project revolves around the usage of triple blended high strength concrete in which the supplementary mineral admixtures used are that of fly ash and silica fume. In addition to these, we are also mixing concrete with steel fibres to enhance its flexural strength parameter. Description of the materials involved is dealt with in subsequent chapters.

\subsection{OBJECTIVE}

As our project title suggests, the objective of our project is to find out the strength parameters, in specific, the compressive and flexural strengths of fibre reinforced triple blended high strength concrete and compare the same with that of ordinary concrete. In turn, our project is aimed towards experimentally proving the advantages of fibre reinforced triple blended concrete over ordinary concrete and thus fostering its usage for not only greater strength and durability but also in view of the economic and environmental considerations previously mentioned. More specifically, the aim of this study is:

- To prepare the concrete cubes \& beams using cement partly replaced by silica fume and fly ash.
- To determine compressive strength of hardened concrete at 28 days of curing \& compare various mixes.

- To determine flexural strength at 28 days of curing \& compare various mixes

In the process of testing, compressive and flexure tests specifications as per IS:516-1959 have been adhered to. The description and specifications of the tests and the apparatus have been dealt with in subsequent chapters.

\section{REVIEW OF LITERATURE}

\subsection{NOTABLE PREVIOUS RESEARCH}

A number of reports have demonstrated that concretes containing combinations of fly ash and silica fume with Portland cement are superior in certain respects to concretes containing Portland cement only. Studies at the Virginia Transportation Research Council have also demonstrated that silica fume added in relatively small amounts to fly ash concrete significantly improves early resistance of the concrete to penetration by chloride ions when tested in accordance with ASTM C1202.4, 5 The type and source of the cement, characteristics and amounts of fly ash, and silica fume affected the results.

\subsubsection{TRIPLE BLENDED CONCRETE}

R.V Balendran, T.M Rana, T. Masqood and W.C Tsong (2002) studied on "strength and durability performance of High Performance incorporating pozzolanas at elevated temperatures". The inclusion of pozzolanas like fly ash and silica fume enhances the properties of concrete both in fresh and hardened states. In the case of high performance concrete (HPC), their role in enhancing the workability, strength and durability is extremely significant.

According to Li and Zhao (2003), blending Fly Ash and Silica Fume presents an excellent behaviour in both short- and long-term compressive strengths and in resistance to $\mathrm{H}_{2} \mathrm{SO}_{4}$ attack; and improves the microstructure and hydration rate. The achievement of these advantages becomes more important for HSC proportioning since HSC requires high amounts of cementitious materials.

Tahir Kemal Erdem and OnderKırca(2009), used the ternary blend of silica fume and fly ash to obtain high strength concrete mix. They have shown that triple blends almost always made it possible to obtain higher strengths than PC (plain concrete) $+\mathrm{SF}$ (silica 
fume) mixtures at all ages provided that the replacement level by Fly Ash (class F) or Fly Ash (class $\mathrm{C}$ or $\mathrm{S}$ ) was chosen properly. They also showed that the improvements in strengths by ternary blends were more significant at 7 and 28 days than at 3 days.

Nassim and Suksawang (2003) in their very comprehensive study have a main conclusion: "Combining silica fume and fly ash enhances the durability and mechanical properties of HPC. In fact, it is highly recommended that a minimum of 5 percent silica fume beaded to fly ash concrete to improve its durability. Moreover, the ductility of concrete increases when comparing to ACI recommendation".

Medhat H. Shehata and Michael D.A. Thomas (2001) have shown use of triple blend (silica fume and fly ash) to suppress expansion due to alkali-silica reaction (ASR) in concrete. They concluded that Practical levels of silica fume and fly ash introduced into high-alkali Portland cement (HAPC) systems were found to be effective in reducing the expansion due to ASR to levels $<0.04 \%$ after 3 years.

So as summarily triple blend of silica fume and fly ash can be use for the following purposes.

- To conserve cement

- To produce high strength concrete

- To control alkali-silica reaction

- To reduce chloride associated corrosion and Sulphate attack

- To increase modulus of elasticity

\subsubsection{FIBROUS-REINFORCED CONCRETE}

Jon M. Rouse and Sarah L. Billington (2007) "creep and shrinkage of high performance fibre reinforced cementitious composites" describes a class of high performance fibre reinforced cementitious composites, referred to as engineered cementitious composites that were studied for its time dependant properties. The material exhibits a pseudo strainhardening response with multiple fine cracking in uniaxial tension. A series of experiments on Fibre reinforced concrete specimens were conducted to provide information about the shrinkage, basic creep, dying creep and shrinkage of concrete were made.

The study of mechanical behaviour of fibre reinforced concrete was conducted by Swamy and Hannat. As a consequence of the above investigation it has been observed that compared to plain concrete there is a substantial increase in the tensile strength, the first crack, flexural strength and ultimate flexural strength of fibre reinforced concrete.

The low fatigue strength of plain concrete is mainly due to the presence of micro cracks at stresses much less than the ultimate stresses and their rapid propagation under repetitive loads. Because of the main characteristics of resistance to crack propagation by the closely spaced fibres in the fibre reinforced concrete, the fatigue strength is very much improved.

Ghosh, Bhattacharya and Chakraborty studied the most important parameters like tensile strength flexural strength of steel fibre reinforced concrete $\mathrm{b}(\mathrm{SFRC})$ which dictate the behaviour. It also looks into the probable effect of fibres on the compressive behaviour of SFRC considering the possibility of fibre buckling in the matrix.

Benson, Nicolaides and Karihaloo deals with the assessment of the distribution of fibres in a class of high performance short steel fibre-reinforced cementitious composites. The effect of mixing procedure and of the shape of the object cast on the distribution of the fibres is assessed using both a nondestructive and a destructive technique.

\subsection{CASE STUDY}

A case study was carried at the University of Melbourne by T.N.Ngo , P.A.Mendis, D.Teo and G.kusuma to assess the performance of a ground floor RC column of a typical office building under a bomb blast. It was found that HSC columns perform better than NSC columns(with the same axial load capacity) when subject to extreme impulsive loading.

A ground floor column (6.4 meters high) of multi-storey building (modified form of a typical building designed in Australia) was analyzed in the case study. The parameters considered were the concrete strength (40MPa for NSC column and $80 \mathrm{MPa}$ for HSC column) and spacing of ligatures (400 $\mathrm{mm}$ for ordinary detailing-OMRF and $100 \mathrm{~mm}$ for special seismic detailing-SMRF). It has been found that with increasing concrete compressive strength, the column size can be effectively reduced. In this case the column size was reduced from $500 \mathrm{x}$ 900 for the NSC column down to $350 \times 750$ for HSC column while axial load capacities of the two columns are still the same. The blast load was calculated based on data from the Oklahoma bombing report (ASCE 1996) with a standoff 
distance of $11.2 \mathrm{~m}$. The simplified triangle shape of the blast load profile was used. The duration of the positive phase of the blast is 1.3 milliseconds.

It can be seen that under this close range bomb blast both columns failed in shear. However, the $80 \mathrm{MPa}$ columns with reduced cross section have a higher lateral deflection, which shows a better energy absorption capacity compared to that of 40MPa columns.

Results from the study show that shear failure was the dominant mode of failures for close range explosion. HSC columns were shown to perform better than NSC columns (with the same axial load capacity) when subjected to extreme impulsive loading; they also had higher energy absorption capacity.

On the basis of the literature reviewed with respect to "EFFECT OF TRIPLE BLENDS WITH FIBRE ON THE PROPERTIES OF CONCRETE" the experiments were carried out, which is reflected in the succeeding chapter.

\section{MATERIALS}

\subsection{General}

In this chapter various materials and method of conducting the test was discussed in detail and detailed methodology of the was presented.

\subsection{Materials Used \\ - Cement \\ - Fine aggregates \\ - Coarse Aggregates \\ - Fly Ash \\ - Silica Fume \\ - Steel Fibers \\ - Water \\ - Super Plasticizer}

\subsubsection{CEMENT:}

Cement is an essential component in concrete which has the property of both adhesion and cohesion that helps other ingredients like fine aggregate, coarse aggregate and admixtures to form a uniform and compact paste. Presently, in this work ordinary Portland cement of grade 53 is used.

\subsubsection{FINEAGGREGATE:}

The locally available sand is used as fine aggregate in the present investigation. The sand is free from clayey matter, salt and organic impurities. The sand is tested for various properties like specific gravity, bulk density etc., in accordance with IS 23861963(28). Grain size distribution of sand shows that it is close to the zone 1 of IS 383-1970(29). The properties of sand are shown in table 3. Details of sieve analysis are shown in table 1.

\section{Table- 1 PROPERTIES OF FINE AGGREGATE}

\begin{tabular}{|l|l|l|}
\hline $\begin{array}{l}\text { S.N } \\
\mathrm{o}\end{array}$ & Property & Values \\
\hline 1 & $\begin{array}{l}\text { Specific } \\
\text { gravity }\end{array}$ & 2.68 \\
\hline 2 & Density & $\begin{array}{l}1640 \\
\mathrm{~kg} / \mathrm{m}^{3}\end{array}$ \\
\hline 3 & $\begin{array}{l}\text { Fineness } \\
\text { Modulus }\end{array}$ & 2.78 \\
\hline
\end{tabular}

\subsubsection{COARSE AGGREGATE:}

Coarse aggregates helps in increasing the volume of the concrete, improves hardness and strength. Coarse aggregate considered is of angular crushed shape and $20 \mathrm{~mm}$ size aggregates are used in our work. As per IS 2386-1963 part 3, experiments were performed to determine the fineness modulus, specific gravity

\section{Table- 2 PROPERTIES OF COARSE AGGREGATE}

\begin{tabular}{|l|l|l|}
\hline S.No & Property & Values \\
\hline 1 & Specific Gravity & 2.64 \\
\hline 2 & Density & $1700 \mathrm{~kg} / \mathrm{m}^{3}$ \\
\hline 3 & Fineness Modulus & 7.14 \\
\hline
\end{tabular}

\subsubsection{FLY ASH}

Fly ash constitutes as one of the major waste byproduct obtained from the thermal power plants, on combustion of coal. There are basically two types of fly ash which are class $\mathrm{C}$ and class F. Class $\mathrm{C}$ fly ash is considered as high calcium fly ashes with carbon content less than $2 \%$ and Class $\mathrm{F}$ are generally low calcium fly ashes carbon content varying between $5 \%$ to $10 \%$. Here, Class C fly ash is used in our work. IS 3812 part-1 gives detailed 
specifications about fly ash.

Table- 3 PHYSICAL PROPERTIES OF FLYASH

\begin{tabular}{|l|l|}
\hline Specific gravity & 2.20 \\
\hline Bulk density & $1250 \mathrm{~g} / \mathrm{cm}^{3}$ \\
\hline Specific surface area & $390^{2} / \mathrm{kg}$ \\
\hline
\end{tabular}

\subsubsection{SILICA FUME}

Condensed Silica fume, also known as microsilica, is a dry amorphous powder which, when added with standard cements will increase the durability and strength of the concrete as well as reducing permeability and improving abrasion-erosion resistance. It may also be used in many applications where high strength is required.

Table 4: PHYSICAL PROPERTIES OF SILICA FUME

\begin{tabular}{|l|l|}
\hline Specific gravity & 2.25 \\
\hline Bulk density & $570 \mathrm{~kg} / \mathrm{m}^{3}$ \\
\hline Specific surface area & $150000 \mathrm{~cm}^{2} / \mathrm{g}$ \\
\hline
\end{tabular}

\subsubsection{STEEL FIBRES:}

Steel fibers are used to improve the flexural and tensile property of concrete, by volume of concrete. Here, steel fibers of diameter $0.5 \mathrm{~mm}$ and having length $60 \mathrm{~mm}$ is used.

Table 5: PROPERTIES OF STEEL FIBER

\begin{tabular}{|l|l|}
\hline Ultimate tensile strength & $650 \mathrm{~N} / \mathrm{mm}^{2}$ \\
\hline Young's modulus & $205 \mathrm{~N} / \mathrm{mm}^{2}$ \\
\hline Aspect ratio & 120 \\
\hline
\end{tabular}

\subsubsection{WATER:}

Potable water has been used in the experiment for mixing and curing.

\subsubsection{SUPER PLASTICIZER:}

The super plasticizer used in this experiment is SP430. It is manufactured by FOSROC.

Super plasticizers are new class of generic materials which when added to the concrete causes increase in the workability. These consists mainly of naphthalene or melamine sulphonates, usually condensed in the presence of formaldehyde. Super plastised concrete is a conventional concrete containing a chemical admixture of super plasticizing agent. It enhances workability state to make reduction in water cement ratio of super plasticized concrete, while maintaining workability of concrete

\section{METHODOLOGY}

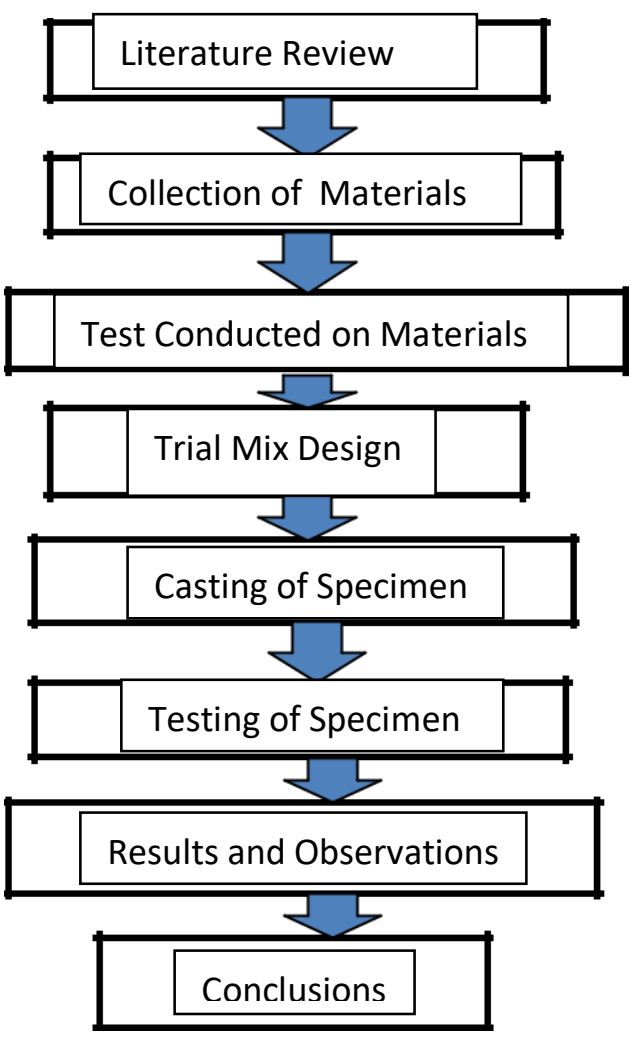

Fig -1: Methodology Of High Strength Concrete 


\section{MIX PROPORTION AND}

EXPERIMENTAL INVESTIGATION

\subsection{DESIGN OF M80 GRADE CONCRETE}

Type of cement: OPC 53 grade

Maximum size of coarse aggregate: $20 \mathrm{~mm}$

Exposure condition: moderate

Type of coarse aggregate: crushed angular shape

Fine aggregate: Zone-I

Design mix target slump: $75 \mathrm{~mm}$

Specific gravity of cement: 2.98

Specific gravity of C.A: 2.64

Specific gravity of F.A: 2.78

Specific gravity of admixture: 1.1

Water absorption of coarse aggregate: $0.6 \%$

Water absorption of fine aggregate: $0.8 \%$

Assumed standard deviation: $5 \mathrm{~N} / \mathrm{mm}^{2}$

\subsection{1) Target mean strength of concrete}

$$
\begin{aligned}
\mathrm{fm} & =\mathrm{fck}+1.65 \mathrm{~S} \\
& =80+1.65 \mathrm{x} 5 \\
& =88.25 \mathrm{~N} / \mathrm{mm}^{2}
\end{aligned}
$$

\subsection{2) Determination of water cement ratio}

As per table 5 of IS 456:2000 for moderate exposure, water cement ratio for target mean strength is 0.31

\subsection{3) Determination of water content}

From table 2 of IS 10262:2009, minimum water content required or $20 \mathrm{~mm}$ size coarse aggregate and water cement ratio 0.31 is $195 \mathrm{~kg} / \mathrm{m}^{3}$

\subsection{4) Calculation of cement content}

water cement ratio $=0.31$ and water content $=195$ $\mathrm{kg} / \mathrm{m}^{3}$

Minimum cement content required $=195 / 0.31$ $=629.03 \mathrm{~kg} / \mathrm{m}^{3}$

\subsection{5) Calculation of volume of coarse \& fine aggregate}

For calculated cement content $=629.03 \mathrm{~kg} / \mathrm{m}^{3}$ and water content $=195 \mathrm{~kg} / \mathrm{m}^{3}$, the density of fresh concrete $=2400 \mathrm{~kg} / \mathrm{m}^{3}$

Therefore, density of total aggregate $=2400$ $(629.03+195)$

$=1575.9 \mathrm{~kg} / \mathrm{m}^{3}$

\subsection{6) Design mix calculation}

For $20 \mathrm{~mm}$ size aggregates, w/c ratio of 0.31 , slump of $75 \mathrm{~mm}$, percentage of fine aggregate $=38 \%$

Density of fine aggregate $=1575.97 *(38 / 100)=$ $598.86 \mathrm{~kg} / \mathrm{m}^{3}$

Density of coarse aggregate $=1575.97-598.86=$ $977.28 \mathrm{~kg} / \mathrm{m}^{3}$

\subsection{7) Mix proportion of M80 Grade concrete:}

Quantity of cement used $=629.03 \mathrm{~kg}$

Quantity of fine aggregate $=598.86 \mathrm{~kg}$

Quantity of coarse aggregate $=977.28 \mathrm{~kg}$

Quantity of water $=195 \mathrm{~kg}$

The design ratio to be followed $=1: 0.95: 1.55$

\subsection{CASTING OF SPECIMENS}

In my present thesis, three sets of concrete specimens were casted and then tested to attain the desired properties. Cubes, beams and cylinders for compressive, flexural and split tensile strength respectively are prepared with fly ash replacement percentage $0 \%, 15 \% \& 30 \%$ and silica fume replacement percentage $0 \%, 6 \%, 12 \% \& 18 \%$ along with addition of steel fibers $0 \%, 0.5 \% \& 1 \%$.

\section{RESULTS \& DISCUSSIONS}

Compressive strength, flexural strength $\&$ split tensile strength tests were conducted for each set of concrete cubes, concrete beams and concrete cylinders respectively to analyze the mechanical behavior of concrete for fly ash replacing cement by $0 \%, 15 \%$ \& $30 \%$ and silica fume by $0 \%, 6 \%, 12 \%$ \& $18 \%$ with addition of steel fibers $0 \%, 0.5 \% \& 1 \%$ after a curing period of 28 days. 
The various strength test that are to be done listed as below.

- Compressive strength

- Split tensile strength

- Flexural strength

\section{Test Specimens}

The test specimens for compressive strength test were made of cubes having a size of $150 \mathrm{~mm} \mathrm{x}$ $150 \mathrm{~mm} \times 150 \mathrm{~mm}$ cast iron steel moulds were used. For each mix proportion three numbers of cubes were cast and tested at the age of 7 days and 28 days. The test specimens for split tensile strength test were made of cylinders having a size of $100 \mathrm{~mm}$ diameter and $300 \mathrm{~mm}$ high cast iron moulds were used. For each mix proportion three numbers of cylinders were cast and tested at 28 days. The test specimens for Flexural strength test were made of prism having a size of $500 \mathrm{~mm} \times 100 \mathrm{~mm} \times 100 \mathrm{~mm}$ cast iron steel moulds were used. For each mix proportion three numbers of prisms were cast and tested at the age of 28 days. Table 6 shows the Details of test specimen.

Table 6. Details of Test Specimen

\begin{tabular}{|c|c|c|c|}
\hline S.NO & NAME OF TEST & $\begin{array}{l}\text { SIZE OF } \\
\text { SPECIMEN } \\
(\mathrm{mm})\end{array}$ & $\begin{array}{l}\text { No. OF } \\
\text { SPECIMEN }\end{array}$ \\
\hline 1 & $\begin{array}{l}\text { Compressive } \\
\text { Strength }\end{array}$ & $\begin{array}{l}150 \times 150 \times \\
150\end{array}$ & 36 \\
\hline 2 & Split tensile test & $150 \times 300$ & 18 \\
\hline 3 & $\begin{array}{l}\text { Flexural strength } \\
\text { test }\end{array}$ & $\begin{array}{l}500 \times 100 \times \\
100\end{array}$ & 18 \\
\hline \multicolumn{3}{|c|}{ Total } & 72 \\
\hline
\end{tabular}

\subsection{COMPRESSIVE STRENGTH RESULTS}

Table 7: Compressive strength values for various replacements of fly ash, silica fume with $0 \%$ steel fibers by volume of concrete for 28 days curing

\begin{tabular}{|l|l|l|l|l|}
\hline $\begin{array}{l}\text { S.N } \\
\text { O }\end{array}$ & $\begin{array}{l}\text { FLY } \\
\text { ASH } \\
(\%)\end{array}$ & $\begin{array}{l}\text { SILICA } \\
\text { FUME } \\
(\%)\end{array}$ & $\begin{array}{l}\text { STEEL } \\
\text { FIBER } \\
(\%)\end{array}$ & $\begin{array}{l}\text { COMPRESSIV } \\
\text { E } \\
\text { STRENGTH(N/ } \\
\left.\text { MM }^{2}\right) \text { 28 DAYS }\end{array}$ \\
\hline 1 & 0 & 0 & 0 & 77.52 \\
\hline 2 & 0 & 6 & 0 & 78.52 \\
\hline 3 & 0 & 12 & 0 & 79.37 \\
\hline 4 & 0 & 18 & 0 & 79.41 \\
\hline 5 & 15 & 0 & 0 & 78.36 \\
\hline $\begin{array}{l}\text { S.N } \\
\text { O }\end{array}$ & $\begin{array}{l}\text { FLY } \\
\text { ASH } \\
(\%)\end{array}$ & $\begin{array}{l}\text { SILICA } \\
\text { FUME } \\
(\%)\end{array}$ & $\begin{array}{l}\text { STEEL } \\
\text { FIBER } \\
(\%)\end{array}$ & $\begin{array}{l}\text { COMPRESSIV } \\
\text { E } \\
\text { STRENGTH(N/ } \\
\left.\text { MM }^{2}\right) \\
\text { DAYS }^{28}\end{array}$ \\
\hline 6 & 15 & 6 & 0 & 79.30 \\
\hline 7 & 15 & 12 & 0 & 80.80 \\
\hline 8 & 15 & 18 & 0 & 80.57 \\
\hline 9 & 30 & 0 & 0 & 78.58 \\
\hline 10 & 30 & 6 & 0 & 79.26 \\
\hline 11 & 30 & 12 & 0 & 80.51 \\
\hline 12 & 30 & 18 & 0 & 79.60 \\
\hline
\end{tabular}

Table 8: Compressive strength values for various replacements of fly ash, silica fume with $0.5 \%$ steel fibers by volume of concrete for 28 days curing

\begin{tabular}{|c|c|c|c|c|}
\hline $\begin{array}{l}\text { S.N } \\
\text { O }\end{array}$ & $\begin{array}{l}\text { FLY } \\
\text { ASH } \\
(\%)\end{array}$ & $\begin{array}{l}\text { SILICA } \\
\text { FUME } \\
(\%)\end{array}$ & $\begin{array}{l}\text { STEEL } \\
\text { FIBER } \\
(\%)\end{array}$ & $\begin{array}{lr}\text { COMPRESSIV } \\
\text { E } \\
\text { STRENGTH(N/ } \\
\left.\text { MM }^{2}\right) \\
\text { DAYS }\end{array}$ \\
\hline 1 & 0 & 0 & 0.5 & 77.58 \\
\hline 2 & 0 & 6 & 0.5 & $\overline{78.72}$ \\
\hline 3 & 0 & 12 & 0.5 & 79.60 \\
\hline 4 & 0 & 18 & 0.5 & 79.53 \\
\hline 5 & 15 & 0 & 0.5 & 78.51 \\
\hline 6 & 15 & 6 & 0.5 & 79.57 \\
\hline 7 & 15 & 12 & 0.5 & 79.90 \\
\hline 8 & 15 & 18 & 0.5 & 79.67 \\
\hline 9 & 30 & 0 & 0.5 & 77.51 \\
\hline 10 & 30 & 6 & 0.5 & 79.58 \\
\hline 11 & 30 & 12 & 0.5 & 79.61 \\
\hline 12 & 30 & 18 & 0.5 & 79.58 \\
\hline
\end{tabular}


Published Online May 2021 in IJEAST (http://www.ijeast.com)

Table 9: Compressive strength values for various replacements of fly ash, silica fume with $1 \%$ steel fibers by volume of concrete for 28 days curing

\begin{tabular}{|l|l|l|l|l|}
\hline $\begin{array}{l}\text { S.N } \\
\text { O }\end{array}$ & $\begin{array}{l}\text { FLY } \\
\text { ASH } \\
(\%)\end{array}$ & $\begin{array}{l}\text { SILIC } \\
\text { A } \\
\text { FUME } \\
(\%)\end{array}$ & $\begin{array}{l}\text { STEEL } \\
\text { FIBER } \\
(\%)\end{array}$ & $\begin{array}{l}\text { COMPRESSIVE } \\
\text { STRENGTH(N/ } \\
\left.\text { MM }^{2}\right) \text { 28 DAYS }\end{array}$ \\
\hline 1 & 0 & 0 & 1 & 80.30 \\
\hline 2 & 0 & 6 & 1 & 81.32 \\
\hline 3 & 0 & 12 & 1 & 81.54 \\
\hline 4 & 0 & 18 & 1 & 81.39 \\
\hline 5 & 15 & 0 & 1 & 81.47 \\
\hline 6 & 15 & 6 & 1 & 81.37 \\
\hline 7 & 15 & 12 & 1 & 82.37 \\
\hline 8 & 15 & 18 & 1 & 81.42 \\
\hline 9 & 30 & 0 & 1 & 80.40 \\
\hline 10 & 30 & 6 & 1 & 81.37 \\
\hline 11 & 30 & 12 & 1 & 81.28 \\
\hline 12 & 30 & 18 & 1 & 81.51 \\
\hline & & & & \\
\hline
\end{tabular}

\subsection{FLEXURAL STRENGTH RESULTS:}

Table 10: Flexural strength values for various replacements of fly ash, silica fume with $0 \%$ steel fibers by volume of concrete for 28 days curing

\begin{tabular}{|l|l|l|l|l|}
\hline $\begin{array}{l}\text { S.N } \\
\text { O }\end{array}$ & $\begin{array}{l}\text { FLY } \\
\text { ASH } \\
(\%)\end{array}$ & $\begin{array}{l}\text { SILIC } \\
\text { A } \\
\text { FUME } \\
(\%)\end{array}$ & $\begin{array}{l}\text { STEEL } \\
\text { FIBER } \\
(\%)\end{array}$ & $\begin{array}{l}\text { FLEXURAL } \\
\text { STRENGTH(N/ } \\
\left.\text { MM }^{2}\right) \text { 28 DAYS }\end{array}$ \\
\hline 1 & 0 & 0 & 0 & 7.45 \\
\hline 2 & 0 & 6 & 0 & 7.39 \\
\hline 3 & 0 & 12 & 0 & 8.41 \\
\hline 4 & 0 & 18 & 0 & 7.56 \\
\hline 5 & 15 & 0 & 0 & 7.55 \\
\hline 6 & 15 & 6 & 0 & 8.55 \\
\hline 7 & 15 & 12 & 0 & 8.64 \\
\hline 8 & 15 & 18 & 0 & 8.47 \\
\hline 9 & 30 & 0 & 0 & 7.60 \\
\hline 10 & 30 & 6 & 0 & 8.46 \\
\hline 11 & 30 & 12 & 0 & 8.47 \\
\hline 12 & 30 & 18 & 0 & 8.59 \\
\hline
\end{tabular}

Table 11: Flexural strength values for various replacements of fly ash, silica fume with $0.5 \%$ steel fibers by volume of concrete for 28 days curing

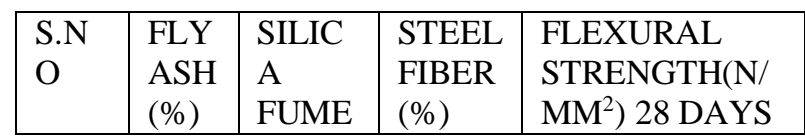

\begin{tabular}{|l|l|l|l|l|}
\hline & & $(\%)$ & & \\
\hline 1 & 0 & 0 & 0.5 & 8.26 \\
\hline 2 & 0 & 6 & 0.5 & 8.81 \\
\hline 3 & 0 & 12 & 0.5 & 8.55 \\
\hline 4 & 0 & 18 & 0.5 & 8.59 \\
\hline 5 & 15 & 0 & 0.5 & 8.72 \\
\hline 6 & 15 & 6 & 0.5 & 8.79 \\
\hline 7 & 15 & 12 & 0.5 & 8.83 \\
\hline 8 & 15 & 18 & 0.5 & 8.73 \\
\hline 9 & 30 & 0 & 0.5 & 8.47 \\
\hline 10 & 30 & 6 & 0.5 & 8.12 \\
\hline 11 & 30 & 12 & 0.5 & 8.74 \\
\hline 12 & 30 & 18 & 0.5 & 8.48 \\
\hline
\end{tabular}

Table 12: Flexural strength values for various replacements of fly ash, silica fume with $1 \%$ steel fibers by volume of concrete for 28 days curing

\begin{tabular}{|l|l|l|l|l|}
\hline $\begin{array}{l}\text { S.N } \\
\text { O }\end{array}$ & $\begin{array}{l}\text { FLY } \\
\text { ASH } \\
(\%)\end{array}$ & $\begin{array}{l}\text { SILIC } \\
\text { A } \\
\text { FUME } \\
(\%)\end{array}$ & $\begin{array}{l}\text { STEEL } \\
\text { FIBER } \\
(\%)\end{array}$ & $\begin{array}{l}\text { FLEXURAL } \\
\text { STRENGTH(N/ } \\
\left.\text { MM }^{2}\right) \text { 28 DAYS }\end{array}$ \\
\hline 1 & 0 & 0 & 1 & 7.54 \\
\hline 2 & 0 & 6 & 1 & 7.83 \\
\hline 3 & 0 & 12 & 1 & 8.13 \\
\hline 4 & 0 & 18 & 1 & 8.04 \\
\hline 5 & 15 & 0 & 1 & 7.74 \\
\hline 6 & 15 & 6 & 1 & 8.03 \\
\hline 7 & 15 & 12 & 1 & 8.97 \\
\hline 8 & 15 & 18 & 1 & 8.27 \\
\hline 9 & 30 & 0 & 1 & 7.64 \\
\hline 10 & 30 & 6 & 1 & 7.95 \\
\hline 11 & 30 & 12 & 1 & 8.22 \\
\hline 12 & 30 & 18 & 1 & 8.16 \\
\hline
\end{tabular}

\subsection{SPLIT TENSILE STRENGTH RESULTS}

Table 13: Split tensile strength values for various replacements of fly ash, silica fume with $0 \%$ steel fibers by volume of concrete for 28 days curing

\begin{tabular}{|l|l|l|l|l|}
\hline $\begin{array}{l}\text { S.N } \\
\text { O }\end{array}$ & $\begin{array}{l}\text { FLY } \\
\text { ASH } \\
(\%)\end{array}$ & $\begin{array}{l}\text { SILIC } \\
\text { A } \\
\text { FUME } \\
(\%)\end{array}$ & $\begin{array}{l}\text { STEEL } \\
\text { FIBER } \\
(\%)\end{array}$ & $\begin{array}{l}\text { SPLIT TENSILE } \\
\text { STRENGTH(N/ }_{\left.\mathrm{MM}^{2}\right)} \text { 28 DAYS }\end{array}$ \\
\hline 1 & 0 & 0 & 0 & 6.30 \\
\hline 2 & 0 & 6 & 0 & 6.36 \\
\hline 3 & 0 & 12 & 0 & 6.45 \\
\hline 4 & 0 & 18 & 0 & 6.64 \\
\hline 5 & 15 & 0 & 0 & 6.56 \\
\hline
\end{tabular}




\begin{tabular}{|l|l|l|l|l|}
\hline 6 & 15 & 6 & 0 & 7.66 \\
\hline 7 & 15 & 12 & 0 & 7.74 \\
\hline 8 & 15 & 18 & 0 & 7.46 \\
\hline 9 & 30 & 0 & 0 & 6.55 \\
\hline 10 & 30 & 6 & 0 & 7.45 \\
\hline 11 & 30 & 12 & 0 & 7.64 \\
\hline 12 & 30 & 18 & 0 & 7.45 \\
\hline
\end{tabular}

Table 14: Split tensile strength values for various replacements of fly ash, silica fume with $0.5 \%$ steel fibers by volume of concrete for 28 days curing

\begin{tabular}{|l|l|l|l|l|}
\hline $\begin{array}{l}\text { S.N } \\
\text { O }\end{array}$ & $\begin{array}{l}\text { FLY } \\
\text { ASH } \\
(\%)\end{array}$ & $\begin{array}{l}\text { SILIC } \\
\text { A } \\
\text { FUME } \\
(\%)\end{array}$ & $\begin{array}{l}\text { STEEL } \\
\text { FIBER } \\
(\%)\end{array}$ & $\begin{array}{l}\text { SPLIT TENSILE } \\
\text { STRENGTH(N/ }_{\left.\mathrm{MM}^{2}\right)} \text { 28 DAYS }\end{array}$ \\
\hline 1 & 0 & 0 & 0.5 & 7.24 \\
\hline 2 & 0 & 6 & 0.5 & 7.55 \\
\hline 3 & 0 & 12 & 0.5 & 7.52 \\
\hline 4 & 0 & 18 & 0.5 & 7.64 \\
\hline 5 & 15 & 0 & 0.5 & 7.72 \\
\hline 6 & 15 & 6 & 0.5 & 7.74 \\
\hline 7 & 15 & 12 & 0.5 & 7.86 \\
\hline 8 & 15 & 18 & 0.5 & 7.74 \\
\hline 9 & 30 & 0 & 0.5 & 7.43 \\
\hline 10 & 30 & 6 & 0.5 & 7.14 \\
\hline 11 & 30 & 12 & 0 & 7.72 \\
\hline 12 & 30 & 18 & 0 & 7.44 \\
\hline
\end{tabular}

Table 15: Split tensile strength values for various replacements of fly ash, silica fume with $1 \%$ steel fibers by volume of concrete for 28 days curing

\begin{tabular}{|l|l|l|l|l|}
\hline $\begin{array}{l}\text { S.N } \\
\text { O }\end{array}$ & $\begin{array}{l}\text { FLY } \\
\text { ASH } \\
(\%)\end{array}$ & $\begin{array}{l}\text { SILIC } \\
\text { A } \\
\text { FUME } \\
(\%)\end{array}$ & $\begin{array}{l}\text { STEEL } \\
\text { FIBER } \\
(\%)\end{array}$ & $\begin{array}{l}\text { SPLIT TENSILE } \\
\text { STRENGTH(N/ }_{\left.\text {MM }^{2}\right)} \text { 28 DAYS }\end{array}$ \\
\hline 1 & 0 & 0 & 1 & 6.53 \\
\hline 2 & 0 & 6 & 1 & 6.82 \\
\hline 3 & 0 & 12 & 1 & 7.13 \\
\hline 4 & 0 & 18 & 1 & 7.05 \\
\hline 5 & 15 & 0 & 1 & 6.63 \\
\hline 6 & 15 & 6 & 1 & 7.38 \\
\hline 7 & 15 & 12 & 1 & 7.95 \\
\hline 8 & 15 & 18 & 1 & 7.25 \\
\hline 9 & 30 & 0 & 1 & 6.64 \\
\hline 10 & 30 & 6 & 1 & 6.93 \\
\hline 11 & 30 & 12 & 1 & 7.24 \\
\hline 12 & 30 & 18 & 1 & 7.14 \\
\hline
\end{tabular}

\section{CONCLUSION}

The following conclusions were drawn from the results obtained from the experiments:

1. It is observed that compressive strength for every concrete mix has failed to reach beyond target mean strength but compressive strength for every concrete mix having some percentage of fly ash, silica fume and steel fibers is higher than the compressive strength of control concrete specimen for 28 days curing.

2. It is examined that highest compressive strength of $81.37 \mathrm{~N} / \mathrm{mm}^{2}$ is attained for a mix of concrete having $15 \%$ fly ash and $12 \%$ silica fume with $1 \%$ steel fibers when compared to other concrete mixes.

3. It is noticed that flexural strength results for concrete mixes included with fly ash, silica fume and steel fibers are greater than the flexural strength obtained for ordinary concrete samples without fly ash, silica fume and steel fiber for 28 days curing.

4. Maximum flexural strength of $8.97 \mathrm{~N} / \mathrm{mm}^{2}$ is observed at a replacement of $15 \%$ fly ash and $12 \%$ silica fume with $1 \%$ steel fibers when compared to other concrete mixes.

5. It is further noticed that split tensile strength results for concrete mixes included with fly ash, silica fume and steel fibers are greater than the split tensile strength obtained for ordinary concrete samples without fly ash, silica fume and steel fiber for 28 days curing.

6. Highest split tensile strength of $7.95 \mathrm{~N} / \mathrm{mm}^{2}$ is observed at a replacement of $15 \%$ fly ash and $12 \%$ silica fume with $1 \%$ steel fibers when compared to other concrete mixes.

\section{REFERENCES}

[1] Manu S Nadesan \& P. Dinakar (2017) "Structural concrete using sintered fly ash light weight aggregate". Construction and Building Materials, Volume 154, Pages 928944.

[2] Kanwaldeep Singh, Sukhpal Singh, A,S Dhaliwal \& Gurmel Singh (2015) "Gamma radiation shielding analysis of lead fly ash concretes". Applied Radiation and Isotopes, Volume 95, Pages 174-179.

[3] Harjinder Singh Mann, G.S Brar \& G.S Mudahar (2016) "Gamma ray shielding effectiveness of novel light weight clay fly 
ash bricks". Radiation Physics and Chemistry, Volume 127, Pages 97-101

[4] P T.S Ramesh Babu \& D. Neeraja (2017) " $A$ experimental study of natural admixture effect on conventional concrete and high volume class F fly ash blended concrete". Case Studies in Construction Materials, Volume 6, Pages 43-62.

[5] S. Jeeva Chithambaram \& Sanjay Kumar (2017) "Flexural behavior of bamboo based ferrocement slab panels with fly ash". Construction and Building Materials, Volume 134, Pages 641-648.

[6] Mehran Khan and Majid Ali (2019) "Improvement in concrete behavior with fly ash, silica fume and coconut fibers". Construction and Building Materials, Volume 203, Pages 174-187.

[7] H. Suleyman Gokce, Daniel Hatungimana \& Kambiz Ramyar (2019), "Effect of fly ash and silica fume on hardened properties of foam concrete". Construction and Building Materials, Volume 194, Pages 1-11.

[8] Jianhe Xie, Jianglin li \& Lijuan Li (2019) "Combination effects of rubber and silica fume on the fracture behavior of steel fiber recycled aggregate concrete". Construction and Building materials, Volume 203, Pages 164-173.

[9] M. Rostami \& K. Behfarnia (2017) "The effect of silica fume on durability of alkali activated slag concrete". 